\title{
Image of the Noble Abdelmelec in Peele's The Battle of Alcazar
}

\author{
Fahd Mohammed Taleb Al-Olaqi ${ }^{1}$ \\ ${ }^{1}$ Department of English \& Translation, University of Jeddah, Kingdom of Saudi Arabia \\ Correspondence: Fahd Mohammed Taleb Al-Olaqi, Department of English \& Translation, Faculty of Science \\ and Arts - Khulais, University of Jeddah, Saudi Arabia. P. O. B. 355, Khulais 21921, Kingdom of Saudi Arabia. \\ E-mail: falolaqi@uj.edu.sa
}

Received: March 30, 2016 Accepted: April 18, 2016 Online Published: April 28, 2016

doi:10.5539/ells.v6n2p79 URL: http://dx.doi.org/10.5539/ells.v6n2p79

\begin{abstract}
There is no ambiguity about the attractiveness of the Moors and Barbary in Elizabethan Drama. Peele's The Battle of Alcazar is a historical show in Barbary. Hence, the study traces several chronological texts under which depictions of Moors of Barbary were produced about the early modern stage in England. The entire image of Muslim Moors is being transmitted in the Early Modern media as sexually immodest, tyrannical towards womanhood and brutal that is as generated from the initial encounters between Europeans and Arabs from North Africa in the sixteenth century and turn out to be progressively associated in both fictitious and realistic literatures during the Renaissance period. Some Moors are depicted in such a noble manner especially through this drama that has made them as if it was being lately introduced to the English public like Muly (Note 1) Abdelmelec. Thus, the image of Abdelmelec is a striking reversal of the traditional portrayal of the Moors. This protagonist character is depicted as noble, likeable and confident. He is considerately a product of the Elizabethan playwrights' cross-cultural understanding of the climatic differences between races of Moorish men.
\end{abstract}

Keywords: Abdelmelec, the Muly, the noble Other, Barbary, Moors, Sabastian

\section{Introduction}

English Renaissance information about the East might have been dense. Jesus Casellas as states that the depiction of Morocco in the Elizabethan stage is associated to and informed by a prosperous travel and historical literature that enlarged the curiosity and charmin the Oriental world. To exploit the new trade route with Morocco was to improve and establish strong sources for commerce with the Muslim Orient (Casellas, 1998, p. 203). Louis Wann remarks that the interest in the Moors comes clearly next after the Turkish race (Wann, 1915, p. 439). George Peele's The Battle of Alcazar is a historical Oriental playof Barbary. It is a portrait of Moors and Barbary with allusions, misrepresenting and demeaning to the Moors. It draws on the army antagonism and cultural rivalry between Muslims and Christians skilled at that time and it has been the source for the predominant origin of Islamic beliefs throughout the Renaissance Period. It is in this era that the interest of the Englishmen in "the presentation of Oriental characters, life, history, and customs was strongest" (Wann, 1915, p. 426). Despite that, Peele successfully plans a historical landscape that sorts sense of The Battle of Alcazar as textually designed and enclosed by the mutable ethnic background of Early Modern England. North African Moors, however, were generalized to be noble, cultured, and economically savvy as a result of "English attempts at cooperative trade with the Islamic nations of the region, namely Morocco" for the first time after the crusading wars (Colley, 2002, p. 43; Matar, 1996, p. 39). The portrayal of the Moroccan ambassador works to draw attention of the political relations that frame a culture's "racial imagination" just as efficiently as the fictional presentation. Consequently, "Elizabethans and Foreigners" grow into a prototypical for a fictional exploration that links the alleged divide among "social" and "literary" accounts (Hunter, 1978, p. 37).

The representation of Morocco on the Elizabethan stage is interrelated to and well-versed by a prosperous travel and antique literature that augmented the interest in the Oriental world. The new business routes with Morocco have matured for solid sources with the Near Orient (Hunter, 1978, p. 37). Matar finds out that "the Moors and Turks were 'everywhere,' - not just in the literary imagination of English dramatists and poets, but in the streets, the sea towns, the royal residences, the courts, and the jails of Elizabethan, Jacobean, \& Caroline England and Wales" (Matar, 1999, p. 39). The Elizabethan dramatists were not slow to realize the value of Africa as a source of spectacle, plot, character, and imagery. Barbary seems to be the chief kingdom of Africa in Elizabethan Drama. The allusions to Barbary reproduce the significance of the territory and the extraordinary place it has in the 
collective conscience in the West. Peele's The Battle of Alcazar (1594) and John Dryden's Don Sebastian (1689) are two dramas handling the same actions. Heywood's Famous History of the Life and Death of Captain Thomas Stukeley (1605) and The Fair Maid of the West (1610) are established in Morocco. This Oriental setting of the eventhas got its full significance as it is part of the entire framework, theme and indigenous colour produced. The coreinfluence that the shows sought to create is that of a distinction: the manifestation of Englishmen in the mid of enormous events occurring in Barbary. The region is, consequently, symbolized as an exotic land. The European traveller, Leo Joannes Africanusin Geographical Historie of Africa (1550) refers to Barbaryof the Moors, as "the most noble and worthie region of all Africa" and its inhabitants as a "most honest people," "destitute of all fraud and guile," and "imbracing all simplicitie and truth" (Africanus, sigs. D2v, Dlv). In Marlowe's The Jew of Malta, for instance, the term is used to refer to a native of the East Indies: “... the wealthy Moor that in the Eastern rocks $\backslash$ Without control can pick his riches up" (I, I, pp. 20-21).

The political ties between Morocco and Elizabethan England affected the way of representing the native Moors of North Africa on the London stage. In relation to Berbers of North Africa, the preeminent Queen Elizabeth tried to inaugurate associations with Moroccan monarchs on a profit-making and military nature: primary with King Abu Marwan Abd-el-Malek (1576-1578), and well ahead with his heir (and latest Saadi king before the partition of the monarchy) King Ahmad I al-Mansur (1578-1603) (Bak, 1996, pp. 197-210; Matar, 1998, pp. 3-20, 1999, pp. 7-12). In Peele, The Battle of Alcazar holds no less than forty allusions to gold or money, and certainly there is a constantanxiety with economy, employment, business, piracy and privateering, and with the commodification of affection, femininity and alliance (Bartels, 2008, pp. 43-44). The precious gold form Barbary turns out to be proverbial and repeatedly used in the play. Abdelmelec's queen presents Bassa some gold to 'wear thou the gold of Barbary, \And glister like the palace of the Sun' (II, i, pp. 404-405). In the same way, the Prince of Morocco's choice of the golden casket in Shakespeare's The Merchant of Veniceis almost expected to the Elizabethan audience. The Moors were sometimes associated with the occupation of diving for pearls. In Chapman's The Blind Beggar of Alexandria, Aegiale expresses her determination to find Cleanthes in these words: "Or I will Moor-like, learn to swim and dive /Into the bottom of the sea for him" (Parrott, 1914, p. 4). A similar use of the association is also seen in Heywood's The Fair Maid of the Exchange: "The swarthy Moor, diving to gather pearl" (Field, 1850, p. 18). This pearl diving occupation is more characteristic of the African continent and it seems to have been associated with total ecstasy: "I speak of Africa and golden joys" (2 Henry $I V$. V, iii, p. 101).

The Elizabethans' information of the African region and its folks has been misjudged by some early modern critics. However, Peele's statements about Abdelmelec's colour and racial identity are full of suggestions that Elizabethans knew the difference between Moors and Negroes, or that they had heard of Negroes only as slaves. Peele, Shakespeare, Chapman, Heywood and Some writers have comparatively constituted their own identity through representing the other East. Inparticular, a critic like Daniel Vitkus finds that it is the early establishment of cross-cultural identity out of the boundaries between the ideological constructs of East and West, and the hybrid identity assumed by Englishmen who ventured into the "multicultural Mediterranean" (Vitkus, 2003, p. 101). Accordingly, the early British identity was constituted not only in antithetical contrast to Near Eastern cultures, but also by the possibility of assimilation into the Oriental cultures through the good English diplomatic ties with the Ottoman and Barbary Empires were established after 1570 which, as a result, led to launch the Barbary Company to regulate official trade between England and Morocco through the early 1580s. The entire exotic Orient became generally close to England and the commercial and diplomatic connections between England and Morocco particularly helped to create the Elizabethan interest in the Moors and some Moorish nobles during the reign of Elizabeth.

\section{Abdelmelec, the King of Barbary}

The play shows clearly a political conflict among the good and bad Moors. Abdelmelec is described as the legitimate King of Barbary. Peele speaks admirably of him. In fact, in Peele's time, the Moroccan delegation remained for six months in which they had the opportunity to show up Queen Elizabeth's coronation. The throne of Barbary had kept on good and constructive relations with the British monarch. The Moors also upraised as much attraction as revulsion in the minds and hearts of the locals (D'Amico, 1991, p. 36). Therefore, glamorous stories about the East and its people fascinated to the Elizabethan playwrights and viewers alike (Jones, 1965, p. 37). The rationality behind spending Africa as a setting by Elizabethan authors is that such an act, expectedly, would have bred more displays to the auditorium (Jones, 1965, p. 117). Elizabethans must have found stories about the Berbers' monarchs and portrayal of the crown court of the African Negro kings or slave trade charming (Jones, 1965, p. 87). For that reason, Peele's Abdelmelec is a positive image of the righteous and noble other in Elizabethan Drama. This Other's exotic customs, appearances, or behaviours were admired by the Elizabethans. 
Moorish elegance and luxury generated curiosity among Englishmen. Such Moors were no doubt put in flowing Oriental robes and turbans, "after Turkey fashion", as Henry VIII's disguising costume was described (Hall, 2013, pp. 43-44).

Abdelmelec, Muly Mahamet and Muly Mahamet Seth are represented on the Elizabethan London stage in the light of the historical and political perspective at that time. Peele seems politically enthused when he represents the white Abdelmelec and Muly Mahamet Seth as honourable Moors and black Muly Mahamet as a fiend Moor. These figures, in contrast to what some critics propose (Vaughan, 2005, p. 59), do not begin and end like Shakespeare's Othello, as the example of King Abdelmelec in Peele's Battle of Alcazar appears differently to demonstrate. Abdelmelec, a historical character, is depicted by Peele as gallant and righteous, "a perfect expression of Renaissance ideals of kingly virtue" (Bak, 1996, p. 208), contrary to the wicked Muly Mahamet from the same tragedy (Vaughan, 2005, pp. 58-60). As Jonathan Bate suggests, the image of the Moor Muly Molocco or Abd-el-Malek is echoed in the presentation of Muly Mahomet, and Othello in Peele's Battle of Alcazar in Barbary (1598) and Shakespeare's Othello (1607) (Bate, 2001, p. 14).

The subject of Muly Molocco and his death was a popular episode in the last decades of the sixteenth century (Simpson, 1878, p. 140). Peele's Abdelmelec is historically called Muly Abd-el-Malek. The chronological Abd-el-Malek is not so much unalike from the histrionic Abdelmelec exposed by Peele. King Abd-el-Malek was defined as an intelligent leader and a fighting man. He was a multi-lingual who could communicatein Spanish, Italian, as well as Turkish and Arabic (Polemon, 1972, p. 82; Bovill, 1952, p. 38). As a young prince, Abd-el-Malek has to run away his Morocco to the Ottoman Empire to seek protection under the defence of the Turkish Sultan meanwhile his elder brother, Abdullah al-Ghalib, planned to slaughter him and his other brothers to protect the sovereignty of kingdom for his son; Mohamed el-Mutawakel. Abd-el-Malek, as Bovill put it, was responsive of "the European political prospect and had shown friendly feelings and kindness towards Christian Europeans" (Bovill, 1952, p. 38). Bovill's words, incidentally, were written as follows:

The Shereef [Abd el-Malek] gave practical expression to his liking for Europeans inmany ways. He earned wide respect in Europe by his generous treatment of the many Christians captives who fell into the hands of his marauding corsairs. They were charitably treated and protected from undue hardship. During his brief reign he releasedlarge numbers free of ransom- on a single occasion as many as two hundreds. He also built a hospital for Europeans in Marrakech, close to the principal mosque. This magnanimity was as surprising to Europe as it was bewildering to his co-religionists to whom these infidel associates naturally did not commend their shereef..." (Bovill, 1952, p. 39).

Peele had copied the character of Abdelmelec from Polemon's Booke of Battailes (1587) with some modifications to his character. In fact, the Anglo-Barbary relationships were in progress and highlighted by the visit of the Moorish ambassador, Abd-el-Uahed Ben Massaood, to the Elizabethan high court in 1600, in order to explore the possibility of forming an alliance to conquer Spain with a combination of the English navy and African troops (Vaughan, 2005, p. 57). (Note 2) Peele is amongst the first Elizabethan authors to draw a compassionate image of the Moors. Peele plays on racial stereotypes to distance Abdelmelec and make him seem more similar to a Christian king than a Moor or an outsider to other characters. In contrast to other Moors, the historical Abd-el-Malek was quite satisfactorily disposed towards Christians. Indeed, the bygone Abd-el-Malek exhilarated trade with Christian kingdoms and particularly with England (Hakluyt, 1904, VI, pp. 285-294).

Peele's Abdelmelec seems open-minded to Europeans. Abdelmelec is described as courteous, honorable, thrice-puissant and renowned King of Barbary (I, I, p. 20). Abdelmelec, the gallant Moor is the lawful true-succeeding seed in Barbary. Rubin Archissays:

Descended from the line

Of Mahomet, our grandsire Muly Xarif

With store of gold and treasure leaves Arabia,

And strongly plants himself in Barbary;

And of the Moors that now with us do wend

Our grandsire Muly Xarif was the first.

From him well wot ye Muly Mahamet Xeque,

Who in his lifetime made a perfect law,

Confirmed with general voice of all his peers, 
That in his kingdom should successively

His sons succeed. (I, I, pp. 26-36)

Peele's Abdelmelec is the rightful King of Morocco. He shows his intensely national, anti-foreign, and anti-papal spirit. Although this Moorish King Abdelmelec is one of the most important characters in the play, his role is certainly not the most prominent. Moreover, Abdelmelec is also called "Muly Molocco" in other plays including the play called The Famous History of Captain Thomas Stukeley. (Note 3) Captain Thomas Stukeley is the first Englishman to serve the Moorish Muslims and win national acclaim appears in Peele. (Note 4) Abdelmelec, to whom the Presenter is far more sympathetic, is described as "this brave Barbarian Lord" (Act I, 15). It is these aspects related to the Moor figure, claims Mohamed Laamiri, that makes his appearance "an attractive Other and a popular exotic subject which fired the public imagination by the fantastic stories about the Moors and the Barbary States" (Laamiri, 2003, p. 68). For this heroic concept of Abdelmelec, Peele has had the authority of many passages in the prose account of the battle, where he finds promising material to work with, for Polemon's portrait of Abd-el-Malekis a generous one, drawn with real sympathy (Polemon, 1972, p. 114). Peele's Abdelmelec has derived much of its anxious suspense and lurid exoticism from the contemporary English perception of Turkish might and the English engagement with the perilous Mediterranean world.

Peele notably emphasizes the distinctions between white and black Moors. The dignified uncle Abdelmelec is a white Moor. If he is the forerunner of any other character, it is of Shakespeare's Prince of Morocco in The Merchant of Venice. Shakespeare's Morocco is clearly conceived as a prototype of the white Moor of North Africa. The two white Moors are portrayed as noble pious Muslimsin the observance of their religion. They are represented in images of peace, friendship and lustfulness. They are potentially seenin cultural harmony if the Europeans cease to equate their personal nature with their physical appearance. However, Abdelmelec's usurping nephew Muly Mahamet is a dark skinned Moor "who was born of a negro mother" (Castries, 2000, p. 552). Peele's The Battle of Alcazar has featured the first black Moor of any dramatic significance which made the Elizabethan audience excited by the appearance of the black Muslim Moors (Vaughan, 2005, p. 29). The ambitious Muly Mahamet attempts to steal the Barbarian throne from his uncle, Abdelmelec. The play's Presenter narrates, over the use of a dumb display (a noiseless play or performing) that Muly Mahamet has assassinated Abdelmelec's brother Abdelmunen, along with his brothers, two small princes.

The two characters have appeared opposite to each other in The Battle of Alcazar, in which the villain black Muly Mahamet is shown fighting against his dignified uncle Abdelmelec, a white Moor. In contrast to Muly Mahamet, his uncle Abdelmelec, whose historical image stood also higher in the estimation of Englishmen, isdepicted as a just defender of right, the instrument of Nemesis, and quietly confident of victory. On the other hand, Muly Mahamet rants and curses in the name of the classical gods of the lower world, and when Abdelmelec is about reaching the borders of his native city, Muly Mahamet turnshis thoughts and those of his followers to God:

Cease, rattling drums; and, Abdelmelec, here

Throw up thy trembling hands to heaven's throne,

Pay to thy God due thanks, and thanks to him

That strengthens thee with mighty gracious arms

Against the proud usurper of thy right,

The royal seat and crown of Barbary. (I, i, pp. 75-78)

Abdelmelec speaks of one God like Christians do (V, i, pp. 22-25). The Moors and their religion are comparably hostile to idolatry (Hakluyt, 1904, Vol. 5, p. 226). A similar expression occurs in depictions of the Moors. In one of the two most comprehensive reports of a journey to Morocco, Edmund Hogan proclaims that the Moorish monarch, Muly Abd-el-Malek, endured "a greater affection to our Nation then to others because of our religion, which forbid deth worship of Idols"; that he was "greatly in the feare of God"; and that he recognized both the Old and New Testament (Hakluyt, 1904, Vol. 6, p. 426). His issues, Hogan enhances, named him "the Christian king," and though it is uncertain whether he essentially was a Christian, the doubt further imposes the compatibility between Islam and Christianity (Hakluyt, 1904, Vol. 6, p. 428.).

Abdelmelec has the mightiest moral force in the play. From act one, scene one, when Abdelmelec returns to Morocco with a Turkish force to reclaim his birth-night from his usurping nephew, Abdelmelec is unfailingly wise, just, and in the right. He is a gentleman of action whose achievement seems instantly understandable to Elizabethan audience in defeating the Portuguese, because of his position as the King of State of Barbary for its 
strategic geography and for its commercial power in the Mediterranean Sea. Abdelmelec refers to his followers as "our Moors" (I, i, p. 111) and "The Moors that now with us do wend" (I, i, p. 142). He exhorts the soldiers thus: "Sheath not your swords, you Moors of Barbary, /That fight in right of your anointed king (I, i, pp. 194-196). Peele's Abdelmelec has seamlessly intertwined into the consistency of European descriptions about productive passion, making his association to righteous Moors significant than the stereotyped Moor, Muly Mahomet. In fact, in Abd-el-Malek's sovereignty, Hogan states that the Spanish and Portuguese are endorsed to live and exercise their Catholicism in Barbary (Hakluyt, 1904, Vol. 6, p. 287). King Abd-el-Malek formerly wrote to Queen Elizabeth that he was delighted with Hogan, and demanded that England accept a Moroccan delegation in the near future.

Abdelmelec politically over-reads the scenario of the Christian aid to his nephew. So he utilizes the diplomacy with the Portugal State to avoid any military acceleration since King Sabastian has taken a different opinion to support the civil war in Barbary:

I have, in pity to the Portugal,

Sent secret messengers to counsel him.

As for the aid of Spain, whereof they hoped,

We have despatched our letters to their prince,

To crave that in a quarrel so unjust,

He that entitled is the Catholic king,

Would not assist a careless Christian prince.

And, as by letters we are let to know,

Our offer of the seven holds we made

He thankfully receives with all conditions,

Differing in mind [as] far from all his words

And promises to King Sebastian,

As we would wish, or you, my lords, desire (III, ii, pp. 15-27).

In the meantime, Abdelmelec acts as the man of peace. He writes to King Sebastian several letters to give up war preparation and start friendship relations but Sebastian rejects the offer and promises to vanish them. Sebastian says,

These letters sent from your distressed lord

Torn from his throne by Abdelmelec's hand,

Strengthened and raised by furious Amurath,

Import a kingly favor at our hands,

For aid to re-obtain his royal seat,

And place his fortunes in their former height. (II, iv, pp. 5-10)

In fact, this syncretic language of the letters refers to the series of diplomatic correspondences between Queen Elizabeth and Sultan Murad III. This has had some insightful concerns over the religious interactions and political structures between England and Turkey within Peele's play. Lisa Jardine affords an example of this overstretching of the religious attraction between Anglo-Protestants and the Ottomans. Beginning from an investigation of the Elizabeth/Murad letters, Jardine makes the undisputed point that:

The axis around which the Anglo-Ottoman political negotiations were conducted was the supposedly shared values and beliefs of Lutheran Protestantism and Islam (Jardine, 2004, p. 216).

Peele's description of Sultan Amurath as "furious" indicates to the Turkish despotism. Turkey was a violent state determined on world domination. Daniel remarks that "the Turks were the first warlike power in the world. Their discipline, and their military institutions were the object of universal admiration; Travellers and Politicians exhorted the nations of Europe to imitate them,- - and the nations did so" (Daniel, 1966, p. 182). The Ottomans understand the Christian intention to invade Barbary, so quickly they have supported Abdelmelec. It is not a Berbers' civil war, rather it is a crusade to Barbary. However, Peele allows Abdelmelecthe autonomy and capability to handle and move close to the court circle, on the other hand, he retains him always an foreigner, 
always the foreign whose cruelty is less engaged (and so more cruel) than that of Sebastian the European.

King Sebastian of Portugal is mentioned as an admirable and brave prince (II, ii, p. 160), but he is, indeed, presented to be imprudent in attacking Barbary, having been fooled by Muly Mahamet, who is displayed as a Machiavellian villain. On the other hand, the noble righteous Abdelmelec is inexplicable in the modem critical tradition which seeks to name Othello as the first noble, virtuous Moor on the English stage. Abdelmelec, the lawful true-succeeding king of Morocco, is a perfect expression of Renaissance ideals of kingly gratuitous and so contradicts any easy equation of black looks with a black soul, even as he repels the invasion of the Christian king of Portugal, Sebastian. Peele's Presenter proclaims that Sebastian is an honorable and courageous king, but the disputes are never justified by the young king's speeches or actions. Sebastian's honor is confused with ambition, and with a "great desire," not unlike the bright honor that dazzled Portuguese prince. But the historical Sebastian, that Peele knew, was not a very likely hero. In the chronicle as in the play, Sebastian always benefits by contrast with the "barbarous Moor," but suffers by contrast with Abdelmelec, whose courage is not fitful and head-strong but is governed by wisdom such as Sebastian has never possessed.

European Christians have inherited the traditional hostility of the Moors and their religion. Although Prophet Muhammad has no divinity in Islam, Christians were regarding Prophet Muhammad as a false deity till the sixteenth century. The play has been evangelically interpreted the true-succeeding Abdelmelec representing the Godly consciousness, and the ambitious Englishman Stukeley is as the figure of Adam. Abdelmelec looksas a Christ-like and Muly Mahamet and Sabastian are Satans. Peele's viewers have a harder job of two minds between repulsion and identification of moral representation to understand the Christian and Muslim cross-cultures. Actually, Peele was Christian, wrote for a predominately Christian audience, while the play had a Muslim setting. Many of the speeches in the play have a Christian ring. Sabastian describes his campaign as "holy Christian war" (II, iv, p. 78). He admits his lead to a crusade. He says,

To plant the Christian faith in Africa /.../

And God so deal with King Sebastian's soul

As justly he intends to fight for Christ!/.../

This rightful war, that Christians' God will bless (III, iv, 16, pp. 20-23).

It would seem that Peele is trying by those kind of rhetoric lines to flog things along to the battle. In fact, the first ambassador, Hogan, remarks that Christian forces come to Barbary: "To spend their bloods in honour of their Christ" (III, iv, p. 23). Though the myth that a Christian army, assistedby Christ, could accomplishment against the Muslim hordes vanished, Peele's play employs the event in the Elizabethan context. Vitkus writes that the Spanish, Portuguese, English and Dutch were all colonizers and colonized in the sixteenth and seventeenth centuries (Vitkus, 1997, p. 146).

None of this campaign has anything to do with the religion that Abdelmelec professes and everything to do with his political legitimacy. Peele, like Marlowe, never denies that Christianity is true and that its propagation is Good, but he does establish that Christianity must be spread by free conversion rather than conquest (Al-Olaqi, 2015, p. 1735). Peele's play unequivocally rejects the notion that Christian monarchs can simply disregard the right of Muslim monarchs to dominiumby calling an invasion a crusade. Catholic Sebastian recognised the right of Protestant Elizabeth to her territories. The lesson learned at Alcazar is that Muslim Abdelmelec has an equally legitimate claim to his lands. Shortly before entering battle Sebastian declares:

... if our Christ for whom in chief we tight,

Here by to enlarge the bounds of Christendom,

Favour this war... [he will]

Send victory to light upon my crest... (III, iv, pp. 9-11)

Abdelmelec's attitude towards Sebastian is not only free of spite, but it issympathetic to the point of condescension. He considers Sebastian's course misguided, and seeks to dissuade him by peaceful means from joining the cause of Muly Mahamet:

But, for I have myself a soldier been,

I have, in pity to the Portugal,

Sent secret messengers to counsel him. (III, ii, pp. 9-11)

Abdelmelec's approach is thus in line with that of the Presenter towards Sebastian. Abdelmelec's character is not, however, roundly drawn. Peele treats him primarily as the instrument of revenge and as a symbolic contrast to 
the bad Muly Mahamet. In the other round of the battle, Abdelmelec does not wish to combat Sebastian who united the party of his nephew. Abdelmelec, in history besides in this play, was unenthusiastic to fight Sebastian and his Christian marines. He, as stated by Yoklavich, did all at his hand to "avoid battle, and to persuade Sebastian to return home, for he realized thatthe boy had been misled by foolish ambitions and by the lies of Muly Mahamet, who flattered Sebastian into believing that Abd-el-Malek's army would revolt once the Portuguese were in the field" (Yoklavich, 1961, p. 229).

In the end, Sebastian's subsequent defeat gives his words power. In retrospect, he realizes that he has made a great dishonour done to Christendom. These words hail not the rebirth of the crusader ideal, but a divine refutation of the principle that Christians may disregard the rights of Muslims. In the heat of battle, Sebastian recognises the lesson heaven has taught him, groaning as he dies:

Seest thou not Stukeley, O Stukeleyseestthou not

The great dishonour done to Christendom?

Our cheerful onset crust in springing hop /.../

False hearted Mahomet, now to my cost,

1 see thy treachery, warned to beware

A face so full of fraud and villainy. (V, i. pp. 125-130)

Like Marlowe's Orcanes in Tamburlaine, Peele's magnificent and magnanimous King Abdelmelec faces a righteous battle unafraid, and confident that the "proud, invading [King of] Portugal" who rashly seeks through "a quarrel so unjust" will be repulsed (III, ii, p. 150). One of Stukeley's men earlier in the play notes that "the heavens will right the wrongs that they sustain" (II, i, p. 122). Therefore, Abdelmelec retains his throne and Muly Mahomet receives the bonuses of tyranny and evil. For Sebastian, he is upbraided for his audacity in challenging the rightful monarch of a neighbouring nation, just as he himself has warmed the proud Stukeley who is punished for his earlier challenge to the rightful Queen of Ireland. Arguably there is likewise a historical connotation here concerning Spain's invasion of Portugal, which would come two years after the Battle of Alcazar, and about ten years before Peele's play. As Sebastian received his retaliation at the Battle of Alcazar so, it is possibly hinted, Philip II of Spain gets his in the Battle of the Armada:

The heavens will right the mongs that they sustain,

Philip if these forgeries be in thee,

Assure thee king, twill light on thee at last,

And when proud Spain hopes soundly to prevail,

The time may come that thou and thine shall fail. (III, ii, pp. 22-26)

Peele, following Polemon, sets this scene on the frontier of Barbary. Abdelmelec returns from his exile at the court of the Grand Turk, and he now states his right to the throne as he reaches the boundaries of his native land. To greet Abdelmelec, there are his younger brother, Muly Mahamet Seth - his wife, Abdil Rayes, and Abdelmunen's widow, Rubin Archis. About Abdelmelec, he must be imagined as many soldiers and "distressed ladies" as the company could provide.

The name of the Great Turk, Amurath (Murad III) shows up in George Peele's The Battle of Alcazar (1588-1589). Although the plot turns around Abdelmelec, who is pursuing retribution on his immoral nephew, Amurath drives his janissaries and Calcepius Bassa to assist Abdelmelec in the battle. Amurath is portrayed as being the son of "Soliman" (Sultan Suleyman I) in The Battle of Alcazar, but he is historically his grandson (Bekkaoui, 2001, p. 4). During the course of the play, Amurath is admired numerous times, with characteristics or championships such as "mightie", the "Emperor of the East", the "Emperor of the World" and "God of earthly kings". Also the sub-plot copes with the Englishmen, and King of Portugal, who have come to Barbary to preach the Christianity.

\section{Presenter:}

And now behold how Abdelmelec comes,

Uncle to this unhappy traitor-king,

Armed with great aid that Amurath had sent,

Great Amurath, [great] Emperor of the East,

For service done to Sultan Solimon, 
Under whose colors he had served in field,

Flying the fury of this Negro's father,

That wronged his brethren to install his son (I, pp. 42-49).

The point here indicates the Ottoman overseas' policies of Sultan Soilman whose son Amurath is following. Halil Inalcik remarks that the Ottomans had been anxious about the local power of Spain for some period; in 1533, Murad's eminent grandfather, Suleiman I, sent the king of France 100,000 ducats to support a never-entirely-recognized partnership between France, England, and the German princes against Charles V (Inalcik, 1974, p. 52). Through the second half of the sixteenth century, the Ottomans preserved banking associations and investments with France in harmony against Spanish dominion (Ibid). However in The Merchant of Venice, the Prince of Morocco brags of his heroism as a warrior in Sultan Soliman's army. Peele seems unusually fascinated by the Ottoman figure Amurath III. He describes his allure in the mouth of Abdelmelec:

Great Amurath, great Emperor of the world:

The world bear witness how I do adore

The sacred name of Amurath the Great. (I. i. pp. 8-10)

The Turks are usually characterized as valiant, proud-spirited, and cruel. There is practically widespread appreciation for their valour (Wann, 1915, p. 440). As Matar states, "to numerous Britons, the Turks and Moors were men and women they had known, not in fantasy or fiction, but with whom they worked and lived, sometimes hating them yet sometimes accepting and admiring them" (Matar, 1999, p. 6). The Ottoman Sultan Amurath III was unlikeable to Englishmen, as his name became a perfect example for autocracy. Shakespeare's prejudice is interconnected to his perspective against the Turkish Empire. Prince Harry scorns the Turks and their Sultan. Prince Harry says:

...you mix your sadness with some fear,

This is the English, not the Turkish courts;

Not Amurath an Amurath succeeds,

But Harry Harry. (2 Henry IV. 5.2. pp. 46-49)

R. W. Southern understands that the increasing wealth of Europe and the slow decline of the excessive Turkish Empire made a rise of more secular outlook on the world and mainly on Elizabethans (Southern, 1978, p. 13). In historical accounts, England promoted ties and mutual cooperation with Turkey in military establishment. In 1577, one of the initial demonstrations of English-Moorish maritime contacts happened in which Barbary acquired the canon through his trade relationship with England (Matar, 1999, p. 59). The English battled side by side with the Turkish armies against European states. The English ambassador William Harborne attended to the Turkish Sultan Amurath (Murad) III (1574-1595) on a military campaign (Matar, 1988, p. 226; Chew, 1937, p. 15). So many Europeans and Englishmen converted to Islam in the Elizabethan period.

The play is a bloody fight between Moors and Christians. Religious tensions between the followers of Islam and those of Jesus Christ are an inextricable founding point of the Christianity practiced by the nobility in The Battle of Alcazar. Though Islam is not addressed, Abdelmelec's religion also categorizes him as the righteous noble Other, emphasizing and adding depth to the theme of religious difference in the play. Peele projects Abdelmelec as a religious or conservative character. He is a very effective character raising the crescent as his military badge. Abdelmelec says:

Pay to thy God due thanks, and thanks to him

That strengthens thee with mighty gracious arms

Against the proud usurper of thy right. (I. i, pp. 5-7)

The crescent is the symbol of Abdelmelec's Moorisharmy. It is also portrayed as the mark of the Turkish army. Elizabethans generally believe that crescent is to Muslims like the cross is to Christians. In battlefield, Muly Mahamet Seth instructs his army to "Our Moors have seen the silver moons to wave/ In banners bravely spreading o'er the plain/ And in this semicircles have descried" (I. i, pp. 39-41). During Renaissance, Christendom dealt with the crescent as the symbol of its enemy owing to the Turkish threat. The Elizabethan allusion to the "semicircled moon" refers to the Turkish insignia "the crescent" which is in contrast with the Cross for Christians. Marlowe described the crescent as silver and green half-moon in the Turkish wars (Al-Olaqi, 2012, p. 197). Muslims used white crescent on a green flag as an official emblem (Kidwai, 1995, p. 
90).

The Presenter's tone and viewpoint is European, not Moorish. His language supports Abdelmelec like the other characters such as Lady Calsepius Bassaprays gods to back him. She says: "Called for is Abdelmelec by the gods/ To sit upon the throne of Barbary" (I, i, p. 153). In fact, Peele's language suggests a mightily host, though few characters speak, andcertainly very few actors traditionally served to make a crowd on the Elizabethan stage. The following statement of Abdelmelec's cause is promptly delivered:

That you may understand what arms we bear,

What lawful arms against our brothers son,

In sight of heaven, even of mine honors worth,

Truly I will deliver and discourse

The sum of all. (I, I, pp. 22-26)

In these lines, Peele wants to give the impression of Abdelmelec's honor, and sympathetically to restate his claim to the throne. The text illustrates how Peele reworked narration into his theater, for the scene is almost wholly visualized again by the playwright; and although The Second Book of Battles contains all the accounts upon which Abdelmelec based his claim to sovereignty, Peele finds little else there to help him. The legend of the good Abdelmelec concludes suddenly with his death. Only the sudden death of Abdelmelec calls for a particular note here.

Thrice-happy chance it is for thee and thine

That heavens abates my strength and calls me hence.

My sight doth fail; my soul, my feeble soul

Shall be released from prison on this earth:

Farewell, vain world! For I have played my part. (V, i, pp. 22-25)

This passage in Peele's play seems principally incompetent because it shows the protagonist unsuccessful. Peele gives no suggestion of Abdelmelec's serious illness earlier in the play. The sudden stage direction "He dyeth" consequently appears unconsciously employed, as though Peele had spoiled his source material. The reader of the historical account, on the other hand, is prepared for the king's abrupt death. The tragedy ends with the legitimate succession of Muly Mahamet Seth (the historical Ahmad al-Mansur) to the double sovereignty of Morocco and Fez.

The legend of Peele's admiration of Abdelmelec does not halt him from expressing difference between the Moroccan and the English laws of succession: whereas in England the eldest son inherits the throne, but, in Morocco, the law of fratricide permits the ambitious princes to power to kill the presumed heir including family members upon assuming kingship. The violence brought upon Abdelmelec is because of the bad Moor who claimed power to Morocco. The play has also explored the wicked Moors in terms of destructive cultural and religious effects and practices. Therefore, Peele pours out racial views on other barbarous Moors. A clear example of the racist attitude is best seen in representing Muly Mahamet and his son as black pagan Arabs belonging to Prophet Muhammad's clan. According to critical approaches, Moorish cultural identity plays a direct role in the image of Moors' nation. Bhugra defines cultural identity as something related of human's psyche which marks his/herculture (Bhugra, 2004, p. 46). The identity of Moorish Muslims is always described as "black" or "non -white". The Eastern and Islamic characters are only evaluated by the reference to the color; "non -White" or "black" which is a clear prejudice that the Western critics claim that they avoid. The West identifies in a pain of binary opposition in which is summed up as "white, Christians" whereas the Islamic world is described as the other part of the pair; they are non-white, non-Christian and they are named "infidels" (Shaw \& Stravinskas, 1998, p. 535). This racial treatment of the East does not only stop at these markers of the identity; for instance, Edward Said comments on the European treatment of the Eastern people as nothing but "imperialism, racism and ethnocentrism" (Said, 1978, p. 61). Moreover, Said adds:

Only an Occidental could speak of Orientals, for example, just as it was the White Man who could designate and name the coloreds, or non-whites. Every statement made by Orientalists or whitmen (who were usually interchangeable) conveyed a sense of irreducible distance (Said, 1978, p. 63).

To sum, Peele's The Battle of Alcazar is an exotic story about Morocco and its citizens fascinated to the Elizabethan authors and audiences alike (Jones, 1965, p. 37). The Oriental character of Abdelmelec is homogenized as a single figure sharing a common image with his Occidental audience. No surprise, then, if Queen 
Elizabeth "seemed to prefer cooperating with Islam rather than Papal Catholicism." (Matar, 1999, p. 84). It is non-religious and comprises supplementary information about good and bad Moors. Far from being merely colourful or a pretext for moralizing or satirizing, the play often reflects an interest in the Orient as a subject for creativity and imagination. Peele considers the Oriental world as the domain of "war, conquest, fratricide, lust and treachery" in which Wann says this conception "was more or less justified by the actual facts" (Oueijan, 1996, p. 15). It indicates that history has not been written in the scientific spirit like what Peele has done when he gives final emphasis to the death of three kings, and ignores the incidental misfortune of nearly 20,000 overwhelmed Portuguese soldiers. Peele's play shares with the Elizabethan audience of the post-1600 Islamic drama a fear of the temptation of an illusory Islam. The references to crusade that regularly appear in the play do not only demonstrate an awareness of the Islamic world, but it casts as the proper enemy of the English. At the same time, Peele's sense to call for crusade can be a mask for other less honourable motives. In addition, Peele's The Battle of Alcazar demonstrates the possibility of exploring Oriental issues in English or Christian context while invoking Islam as both extreme force and internal possibility. It is in this fearful mode that Islam was increasingly used in the plays of the early 1600s. This tragedy lays, traditionally, in the "princes' funerals." There is a dignity in the closing lines that is seldom achieved elsewhere in the play.

\section{Conclusion}

Exoticism and fascination remain significant elements in exploring the popularity of the Moorish matter in Elizabethan drama. This is evident in the gorgeous and elegant portrait of Barbary portrayed, displaying its states, societies, ethnic groups, customs and religions. Linda McJannet observes that the particular qualities for which early modern European historians admired the Oriental rulers, were "unity, martial excellence, and strict justice, qualities which they sometimes felt were lacking in their own societies" (McJannet, 2006, p. 60). North African culture was associated with learning and civilization, in contrast to the prevailing images of Turks. A Barber could be "brave" rather than "barbarous"; George Peele's The Battle of Alcazar in Barbary contains a panorama of Moors of the same royal family. The evil of them is defeated, and the good is appreciated.

Abdelmelec is, on the whole, reasonable. In Abdelmelec's appearance on the stage, he is represented as strong, honoured and confident. He is considerately an invention of the Elizabethan playwrights' cross-cultural understanding and accord, which has some realization of the climatic differences between races of Moorish men. Chew maintains that "the appreciation of the genial and admirable qualities of Muslims was difficult to cultivate in an age [the Elizabethan Age] when Christian prejudice rendered any defence of Mohammedanism suspect" (Chew, 1937, p. 545). Peele's play suggests that Moors are driven by a complex mixture of passion, self-constraint, and social imperative. It calls into question the moral virtues espoused by both Christians and Moors, since they are used to rationalize things like neglecting one's governmental responsibilities, beheading one's beloved, and drinking the blood of Christians. In this process, the ambiguity of the term "Moor" serves as a pivot point between otherness and selfhood. As the play seems to use it, "Moor" refers not only to a national identity in the world outside the theatre but also the stock character of English drama. In effect, The Battle of Alcazar treats the inhuman figure of the stage Moor as an actual cultural ideal to which the basically human Moorish characters aspire.

\section{References}

Africanus, L. J. (1600). A Geographical Historie of Africa. (Trans. by John Pory). London: G. Bishop.

Al-Olaqi, F. (2012). Marlowe's Tamburlaine (1587) and Islamic Theology. TRAMES, 16(2), 177-201. http://dx.doi.org/10.3176/tr.2012.2.05

Al-Olaqi, F. (2015). The English Koranic Images in Some Literary Writings. Theory and Practice in Language Studies, 5(8), 1730-1740. http://dx.doi.org/10.17507/tpls.0508.26

Bak, G. (1996). Different Differences: Locating Moorishness in Early Modern English Culture. Dalhousie Review, 76(2), 197-216.

Bartels, E. C. (2008). Speaking of the Moor: From Alcazar to Othello (pp. 43-44). Philadelphia: University of Pennsylvania Press. http://dx.doi.org/10.9783/9780812200294

Bate, J. (2001). Othello and the Other: Turning Turk: The Subtleties of Shakespeare's treatment of Islam. The Times Literary Supplement, October, p. 14.

Bekkaoui, K. (2001). In P. George (Ed.), The Battle of Alcazar. Casablanca, Fez: Moroccan Cultural Centre.

Bhugra, D. (2004). Culture and Self-harm. New York: Psychology Press.

Bovill, E. (1952). The Battle of Alcazar; An Account of the Defeat of Don Sebastian of Portugal at El-Ksar 
el-Kebir. London: Batchworth Press.

Casellas, J. L. (1998). The Enemy Within: Otherness in Thomas Dekker Lust Dominion. Sederi, 9, 203-207.

Castries, H. de. (2000). Les Sources Inedites, Angleterre, I. Amsterdam.

Chew, S. C. (1937). The Crescent and The Rose: Islam and England During The Renaissance. New York: Oxford University Press.

Colley, L. (2002). Captives: Britain, Empire and the New World, 1600-1850. London: Jonathan Cape.

D’Amico, J. (1991). The Moor in English Renaissance Drama. Tampa: University of South Florida.

Daniel, N. (1966). Islam, Europe and Empire. Edinburgh: U.P.

Edelman, C. (2005). The Stukeley Plays: The Battle of Alcazar by George Peele, The Famous History of the Life and Death of Captain Thomas Stukeley. Manchester: Manchester University Press.

Field, B. (1850). The Dramatic Works of Thomas Heywood, I, p. 18. (Each play in this volume is separately paginated).

Greg, W. (1907). George Peele' TheBattle of Alcazar. Malone Society Reprints. Oxford: Chiswick Press.

Hakluyt, R. (1904). The Principal Navigations Voyages Traffiques\& Discoveries of the English Nation: Made by Sea or Over-land to the Remote and Farthest Distant Quarters of the Earth at any time within the compasse of these 1600 Yeeres, 12, 1589. Glasgow: James MacLehose and Sons.

Hall, E. (2013). Henry VIII, 1. London: Forgotten Books. (Original work published 1904).

Harris, B. (2000). A Portrait of a Moor. In S. Wells \& C. M. S. Alexander (Eds.), Shakespeare and Race. Cambridge: Cambridge University Press.

Hunter, K. (1978). "Elizabethans and Foreigners," "Othello and Colour Prejudice," Dramatic Identities and Cultural Traditions: Studies in Shakespeare and His Contemporaries. New York: Barnes \& Noble.

Inalcik, H. (1974). The Turkish Impact on the Development of Modern Europe. In K. H. Karpa (Ed.), The Ottoman State and Its Place in World History (51-60, p. 52). Leiden: Brill.

Jardine, L. (2004). Gloriana Rules the Waves: Or, the Advantage of Being Excommunicated (and a Woman). Transactions of the Royal Historical Society, 14, 216. http://dx.doi.org/10.1017/s0080440104000234

Jones, E. D. (1965). Othello's Countrymen: The African in English Renaissance Drama. London: Oxford Univ. Press.

Kidwai, A. R. (1995). Orientalism in Lord Byron's “Turkish Tales”. Lewiston: Mellen University Press.

Laamiri, M. (2003). "Barbary" in British Travel Texts. In A. Temimi \& M. S. Omri (Eds.), The Movement of People and Ideas between Britain and the Maghrib (p. 68). (Zaghouan: Foundation Temimi pour la Recherche Scientifique et "l" Information).

Matar, N. (1988). Islam in Britain: 1558-1685. Cambridge: Cambridge University Press.

Matar, N. (1996). Renaissance and the Turban. In D. Blanks (Ed.), Images of the Other: Europe and the Muslim World Before 1700. Cairo: American University.

Matar, N. (1999). Turks, Moors, and Englishmen in the Age of Discovery. New York: Columbia University Press.

McJannet, L. (2006). The Sultan Speaks: Dialogue in English Plays and Histories about the Ottoman Turks. New York: Palgrave Macmillan.

Oueijan, N. B. (1996). The Progress of an Image: The East in English Literature. New York: Peter Lang.

Parrott, T. M. (1914). The Comedies of George Chapman (p. 4). London.

Polemon, J. (1972). The Second part of the booke of battailes, fought in our age: Taken ovt of the best authors and writers in sundrie languages: published for the profit of those that practise armes, and for the pleasure of such as loue to be harmlesse hearers of bloudiebroiles (1587). Amsterdam: Theatrum Orbis Terrarum.

Said, E. (1978). Orientalism. New York: Vintage.

Shaw, R. B., \& Stravinskas, P. M. J. (1998). Our Sunday Visitor's Catholic Encyclopedia (p. 535). Indian: Our Sunday Visitor Publishing.

Simpson, R. (1878). School of Shakespeare. New York.

Southern, R. W. (1978). The Western Views of Islam in the Medieval Ages. Cambridge: Massachusetts, Harvard 
University Press.

Vaughan, V. M. (2005). Performing Blackness on English Stages, 1500-1800. Cambridge: UP.

Vitkus, D. (1997). Turning Turk in Othello: The Conversion and Damnation of the Moor. Shakespeare Quarterly, 48, 145-177. http://dx.doi.org/10.2307/2871278

Vitkus, D. J. (2003). Turning Turk: English Theater and the Multicultural Mediterranean, 1570-1630. New York. http://dx.doi.org/10.1007/978-1-137-05292-6

Wann, L. (1915). The Oriental in Elizabethan Drama. Modern Philology, XII(January), pp. 423-447. http://dx.doi.org/10.1086/386971

Wells, S., \& Alexander, C. M. S. (2000). Shakespeare and Race. Cambridge: UP.

Yoklavich, J. (1961). The Battle of Alcazar. The Dramatic Works of George Peele (pp. 293-347). New Haven, CT: Yale U P.

\section{Notes}

Note 1. Muly, Maula (or Muley), the imperial title in Morocco, means "lord".

Note 2. See also Bernard Harris, "A Portrait of a Moor" In S. Wells \& C. M. S. Alexander (eds.), Shakespeare and Race (Cambridge: Cambridge University Press, 2000), p. 26.

Note 3. The title "Muly Molocco" was famous than his personal name "Abdelmelec." Titles such as "MullieMolloque", "MullaMaluca," "Molucco" and "Mullucco" are different spelling of the great Moor. See State Papers, Foreign. Elizabeth. 1578-1579 (London, 1903), p. 164; A Dolorous Discourse (1579), sig. A6 V; The Famous History of Captaine Thomas Stukeley, sigs. F4 v - Gi v; Teixeira's Adventure Admirable and its English translation, The Strangest Adventure (1601), p. 12.

Note 4. See also Joseph Candido, "Captain Thomas Stukeley: The Man, the Theatrical Record, and the Origins of Tudor "Biographical" Drama, Anglia, 105(1987), 50-68.

\section{Copyrights}

Copyright for this article is retained by the author(s), with first publication rights granted to the journal.

This is an open-access article distributed under the terms and conditions of the Creative Commons Attribution license (http://creativecommons.org/licenses/by/3.0/). 